\title{
Reflecting the Spirit of Modern-Indonesia through Architecture: The Icono-Symbolical Meanings of Jengki Architectural Style Case Studies: Bandung Polytechnic of Health Building and Bumi Sangkuriang Meeting Hall in Bandung, West Java, Indonesia
}

\author{
Purnama Salura $^{1 *}$, Stephanie Clarissa ${ }^{2}$, Reginaldo Christophori Lake ${ }^{3}$ \\ ${ }^{1}$ Universitas Katolik Parahyangan, Bandung, Indonesia \\ ${ }^{2}$ Cetta Gantari Indonesia Research Centre, Indonesia \\ ${ }^{3}$ Universitas Katolik Widya Mandira, Kupang, Indonesia
}

Purnamasaluras.ps@unpar.ac.id ${ }^{I^{*}, c e r r a g a n t a i i n d o n e s i a @ g m a i l . c o m}{ }^{2}$, reginaldolake@unwira.aci.id ${ }^{3}$

Published: $31^{\text {st }}$ August 2020

\begin{abstract}
The architectural discourse in Indonesia generally focuses on traditional architecture that represents specific regional icons, the synthesis of traditional architecture with European-style architecture, and modern architecture inspired by International Style. This research focuses on the architectural style in Indonesia which flourished in the 1950s, known as the Jengki architectural style. This architectural style is essential in the history of Indonesian architecture, considering that the style reflects the spirit of nationalism and post-colonial Indonesian. This research aims to explore the icons of Jengki architecture, by elucidating the architectural concepts that underlie the two oldest Jengki buildings in Bandung, West Java. The analysis showed that the characteristics of this architectural style shown by the configuration of architectural elements resembling the form of a pentagon, mostly asymmetrical in spatial layout, playful articulation of ornaments, and the use of local materials. The pentagon becomes an icon of Pancasila, which is a foundational principle of the new Indonesian state and symbolize the meaning of nationalism. Thus, the icon which also represents symbolic meaning becomes an essential aspect in the design of Jengki-style buildings in the future. This icon can be an alternative to be applied to modern buildings that are intended to display national icons, rather than particular regional icons. Besides enriching the architectural knowledge of Indonesian architecture, the results of this study are beneficial to architectural practitioners, stakeholders, and architectural conservationists as well.
\end{abstract}

Keywords: Architectural icon, Jengki-style, Modern, Post-Colonial Indonesia

\section{INTRODUCTION}

As one of the cultural artefacts, it is believed that architecture could represent the social conditions of the local community, as well as the development of ideology and political practice adopted by a society (Dovey, 1999; Sudjic, 2005). If the authorities in a particular community refer to specific ideologies, then no doubt all aspects of the life of the people will tend to follow that ideology. Research shows that more than being influenced by technological developments or climatic requirements, the work of architecture tends to reflect the dominating ideology of a specific period (Ismail, et al., 2008; Vale, 2008; Yang, 2014; Minkenberg, 2014).

Historical records show that after the era of Hindu and Islamic Kingdoms, Indonesia had gone through a series of changes of governmental practice, beginning with the Dutch colonial practice in 1800 , until postindependence. These changes also has an impact on the development of its architecture (Chandra, 2012; Salura \& Clarissa, 2018). In line with this development, the historiography of Indonesian architecture generally begins with a review of European-style architecture (Empire Style) which was adopted by the colonial government. Around the 1920s, influenced by anthropological education in the Netherlands, the focus shifted to traditional Indonesian architecture. Departing from the rise of knowledge about traditional architecture, then emerged the Indo-European (Indische) architectural style, which emphasizes the combination of traditional architecture with Dutch architecture (Salura, et al., 2020). Whereas in the 1970s, when the thought of celebrated architects such as Frank Lloyd Wright, Le Corbusier, Walter Gropius was made 
a compulsory reference in Indonesian architecture schools, modern style architecture influenced by International Style also dominated the world of Indonesian architecture (Sudradjat, 1991). Hitherto, architectural works from these periods are often studied by academics and inspired the world of architectural practitioners as well.

It is not well known that in the postindependence period of the 1950s, a new, completely different architectural style emerged. Only a few years later, this style was known as the Jengki architectural style. Jengki architectural style referred to as one of the styles that reflect the spirit of nationalism, freedom and independence of the Indonesian people (Prakoso, 2002). Unfortunately, the political upheaval in Indonesia in the 1970s caused this architectural style to fade and disused, even forgotten. Today, in contrast to the European, Indische, traditional, even modern architectural style which is still frequently studied and used as a design inspiration for practitioners, the Jengki architectural style have received less attention. Appreciations from the society, even from the architectural conservationist, is considered to be very minimal, which can be seen from the scarcity of Jengki-style buildings. This condition is especially unfortunate, as the disperse of Jengki buildings will cause Indonesia to lose a significant moment in the history of its architectural development.

In the context of architectural research, the importance of Jengki architecture is also unequalled with the quantity and quality of academic publications regarding this architectural style. Most of the literature that examines the development of Indonesian architecture negates this style, by stating that in the era of post-independence, the architectural style adopted to be applied in Indonesia is International Style (Kusno, 2000). Moreover, academic publications that provide an in-depth understanding of the underlying concept of Jengki architecture are rarely done. Some of these publications usually focuses on a mere description of the architecture alone, discussing its architectural typology, or even simply discusses the geometric shapes which are applied to the composition of the building (Setyabudi et al., 2011; Susilo, 2009; Susilo, et al., 2012; Widayat, 2006; Ratri, 2016). However, none of the researches has discussed the future of Jengki architectural style, the substantial qualities that make the Jengki architecture sustained over extended periods; and how this style could be applied in the design of contemporary buildings. Publications in the form of documentation is an effort that needs to be appreciated. On the other hand, the main concern is that mere documentation of Jengki buildings without an in-depth understanding will cause designers to simply mimic its architectural elements or ornamentations (Ismail et al., 2008; Kurniawan \& Kusumawardhani, 2012; Sholihah, et al., 2019). After all, it was the practice of this misplaced-eclectic that led to the aversion of Jengki-style buildings.

Based on these arguments, this research aims to explore the concept that underlies the creation of Jengki-style architecture. However, the study is not intended for a mere "romanticism", but instead focused on the exploration of Jengki architectural icons to be applied to the design of contemporary buildings in the future. Thus, this research is useful for enriching the vocabulary of architectural style while promoting new alternative concepts about architectural styles in Indonesia. Besides beneficial for the development of architectural knowledge, this research can also be as a source of inspiration for practitioners which intended to design a building that reflects the spirit of Indonesia, without having to refer to particular regional icons. Visually, the application of this architectural style certainly adds to the diversity of architectural forms in Indonesia, which has been dominated by modern, traditional architecture, or a combination of both. As for the general public, including decision-makers and architectural conservationists, the results of this study are expected to be a medium to introduce Jengki architectural style and highlighting the significance of this architectural style as a part of cultural heritage.

\section{MATERIALS AND METHODS}

\subsection{Case study}

Literature review shows that Jengki's architectural style is a style that was conceived by President Soekarno after Indonesian independence (Ardhiati, 2005). Nonetheless, the idea of promoting architecture to develop a sense of nationalism was already put forward by Soekarno in 1930. Realizing that the Indonesians must unite to fight against colonialism, there has been an agreement to build Indonesia's national identity that is free from the spirit of regionalism or specific ethnic alone (Sukarno, 2019; Gielbels, 2015). In 1945, the spirit of nationalism gave birth to the Pancasila as the philosophical basis of an independent Indonesia. Etymologically, Pancasila comes from Sanskrit; 
panca means five, while sila means principles. The underlying concept based in the awareness to unite as a nation, the humanity to prevent the emergence of chauvinism due to excessive worship of one's nation, democracy that creates social justice for all people, and creating a nation that is devoted to the one and only God (Aning, 2019). All of these principles are based on the unique traditions of the Indonesian people, namely 'gotong-royong'; which describes a state of mutual cooperation of all people (Fig. 1). In 1950, five years after the declaration of Indonesian independence and establishing Pancasila as the basis of the new state, this spirit was transformed into an architectural style that freeing itself from everything that related to colonialism; and to no longer applied the European or even Indische style to the architectural works.
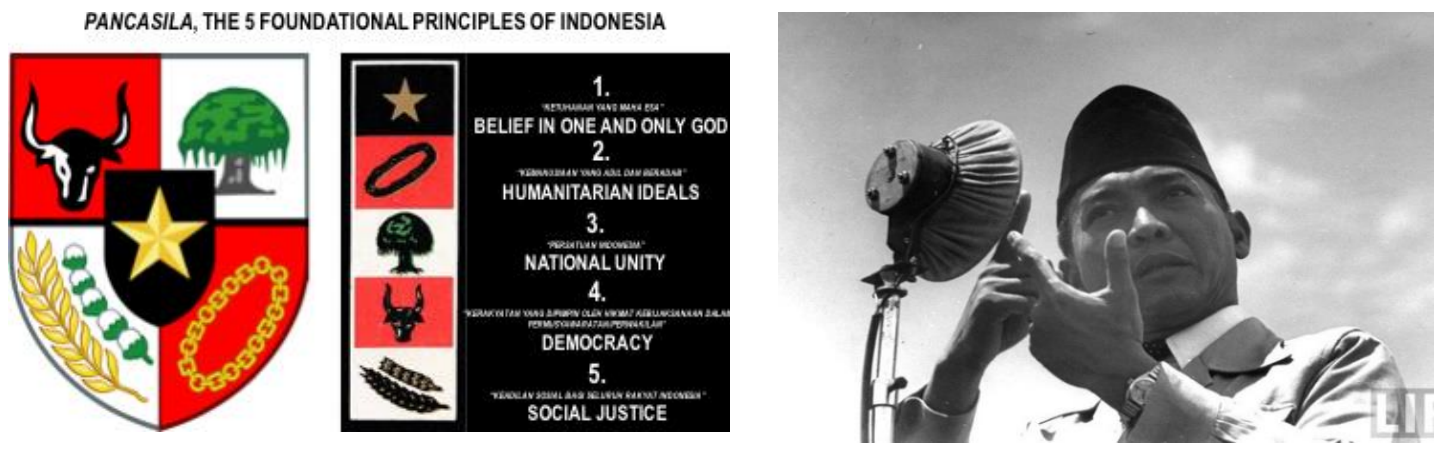

Fig. 1 President Soekarno while delivering the speech about Pancasila, the 5 symbolic principles as the foundation for independent Indonesia Source: (Zakky, 2018; Dariyanto, 2016)

Hitherto, the origin of the term Jengki architecture itself tends to be speculative. Some opinions say that the term 'Jengki' comes from the word 'Yankee', which is New England people who live in the northern America (Watson, 1851). These people were the vanguard of the resistance against Britain, which had for years colonized America; thus, this word implying a spirit of anti-colonialism. This research will not speculate further of the etymology, but rather focuses on the iconic meanings of architectural style typical of Indonesia, which appeared in the era of the 1950s.

As a man with a grandeur ambition to promote the independent Indonesia, Soekarno wanted Jakarta, the capital city of Indonesia, to be comparable to other capital of powerful developed countries. In addition to carrying out massive construction with a master plan of highrise buildings, national monuments, and sports stadiums, he also built a housing complex in Kebayoran, South-Jakarta. These houses are two-story building, with a side elevation of the upper floor are shaped pentagon. These characteristics are then known as Jengki architecture (Mariana, 2013). This architectural style then spread to other prominent cities in Indonesia, such as Bandung, the capital city of Jengki architectural style at that time was reflected in the decision of the stakeholders of Societeit Concordia to create new buildings in
West Java. In Bandung, there are some of the oldest Jengki buildings in Indonesia that accommodate public functions. Moreover, all of these buildings' architectural elements tend to be authentic.

Although it is generally known that the Kebayoran housing is the first Jengki-style architecture in Indonesia, the historical record shows that before the housing was built in 1955 , Soesilo and several architects from the "Technische Hogeschool" (Bandung Institute of Technology) had already designed the Jengki style building. It is not surprising, as Bandung was the centre of architectural development at that time. In this city, there are two oldest Jengki-style building: the building of Bandung Polytechnic of Health (BPH), which was built around 1947, and Bumi Sangkuriang (BS) Meeting Hall which was built in 1957 (Amelita, 2012; Eranio, 2015).

The building of Bandung Polytechnic of Health formerly serves as a dormitory for nurses; however, the overall shape of the building has remained relatively unchanged. The spirit of independence and nationalism was still vigorously prevailed when Bumi Sangkuriang Meeting Hall (formerly Societeit Concordia) was built a decade later. The popularity of this style. Even though it was built more than 70 years ago, both of these buildings still have a complete and relatively authentic architectural 
elements. From these two buildings, we could learn the characteristics of Jengki architectural style as the initial presentation of the style. Therefore, both are considered suitable to be the case studies. The location and the photographs of the two case studies can be seen as follows (Fig. 2-4)
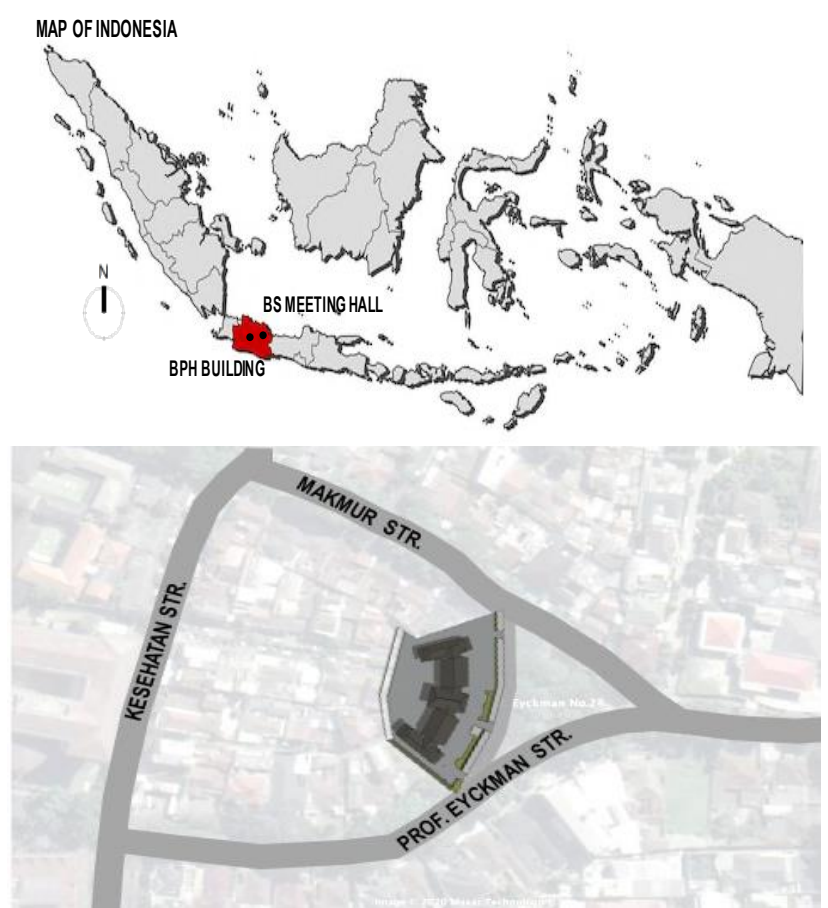

(a) The location of Bandung Polytechnic of Health (BPH) Building

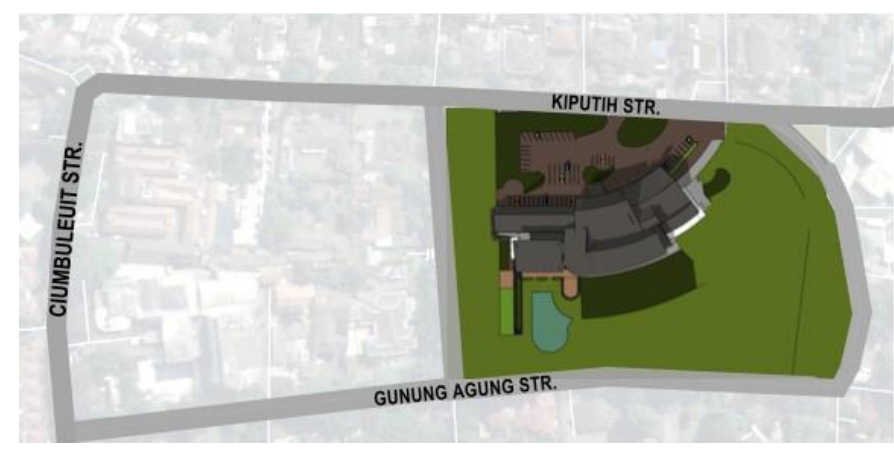

(b) The location of Bumi Sangkuriang (BS) Meeting Hall

Fig. 2 The location of the case studies

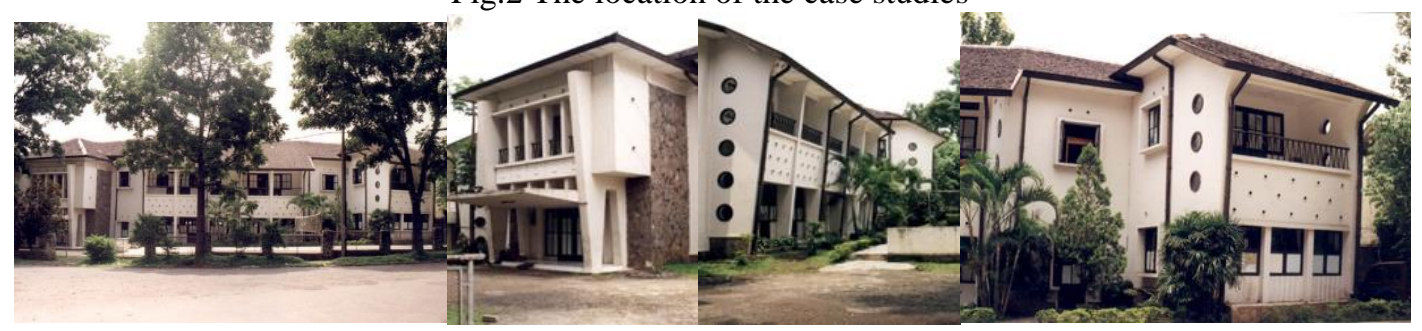

Fig. 3 Documentation of BPH Building

Source: (Amelita, 2012) 


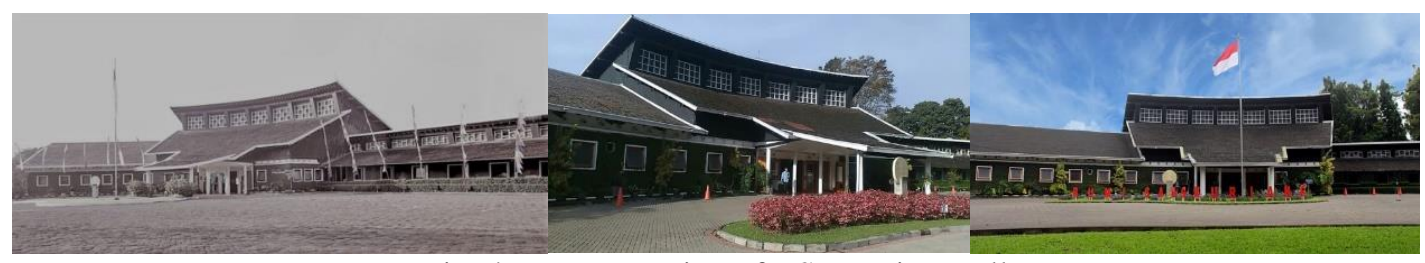

Fig. 4 Documentation of BS Meeting Hall

Source: (Khalil, 2017)

\subsection{Analytical methods}

As explained in the introduction, this research aims to explore the concepts underlying Jengki architectural icons to be applied to modern buildings in the future. The term icon was first used in the 15th century, referring to pictures, figures, or representations. Furthermore, in the early 19th century, the celebrated philosopher Charles Sanders Peirce interpreted this term as one type of sign which was interpreted based on its similarity with other signs (Peirce, 1991; Merrell, 1997; Deledalle, 2000). For example, a photo of an object can be said to be an icon of the object itself. The icon is juxtaposed with another type of signs which based on causality (index) and based on convention (symbol). Studies in the area of cognitive psychology show that a sign that has a similarity relation with other signs are considered as the most easily understood by human beings so that exchanging information via an iconic sign is regarded as the most effective compared with other types (Sadowski, 1957).

In architectural discourse, the term icon put forward by Peirce emerged when architects began to realize that the discussion of architecture was not enough to focus solely on the function and articulation of building forms alone, then began to involve aspects of meaning. Eventually, the term icon is also giving birth to other terms such as iconography and iconology in the field of visual arts, as well as the term 'iconic buildings' in architecture (Panofsky \& Panofsky, 1972). In today's public opinion, the definition of 'iconic architecture' tends to focus on the relationship of architecture with transnational capitalism; and sometimes even reduced and misinterpreted as mere "famous architecture", whether in terms of the appearance of the building or of its designers (Smith, 2003; Tombesi, 2005; Crysler, Cairns, \& Heynen, 2012; Harland \& Liguori, 2016; Sklair, 2011; 2017; Freeman, 2013). Although the definition this term tends to vary, even sometimes shifted from the initial definition, the terms containing the word 'icon' has always focused on: 1) a representation that shows similarity with the phenomenon or other object, and 2) how these representations are interpreted (given meaning) by humans. It can be concluded that the understanding of icons in architecture cannot be separated from the understanding of the meaning associated with the icon itself.

In line with this theoretical stance, this research is based on the understanding that the users and observers always interpret every piece of architectural works (Salura, 2015; 2018a). It is also believed that they already possess specific vocabularies of architectural forms and other objects that have existed in this world. A new form that is seen by observers then will be compared with other forms similar to these vocabularies. Thus, associated with an understanding of icons, an architectural element can be a replica of other objects, both architectural and non-architectural objects. Architectural elements that are replicas of these objects can be classified into the type of 'pure iconic'. However, besides from being a pure iconic alone, architectural elements can also have a similarity with objects or other concepts produced through particular conventions. This type of architectural icons has the meaning of 'icono-symbolical' relationship with other objects, concepts, or ideological stance.

Based on this understanding, the analysis steps are formulated as follows:

Firstly, describing the architectural properties and composition of the two study cases, starting from the scope of the surrounding environment, i.e. how the building is observed in the context of other buildings in the environment, to the scope of the inner spatial configuration (Salura, 2018b; 2018c). Based on this in-depth description, it could be seen whether the dominant property or configuration has similarity to the shape of other objects or other architectural style characteristics. Likewise, it could be seen whether, following the spirit and political context at the time, the building's expression was able to represent the ideologies of nationalism, anti-colonialism, and postcolonial freedoms. 
Secondly, elucidating the underlying concept of Jengki architectural style, as well as interpreting the relationship between the most dominant characteristic of these Jengki buildings and its probabilities to sustain over long periods of time. Moreover, the discussion does not merely focus on the iconic significance of Jengki architecture but also showed the future of these icons to be applied in the design of contemporary buildings.

\section{RESULT AND DISCUSSION}

In line with the analytical methods, this first step focused on the description of building expression as observed from the surrounding environment, site, and inner space. In line with the literature reviews, which state that the Jengki architectural style was signified by the presence of pentagonal shape, the description focused on the pentagonal shape that dominates the overall expression of the buildings.

\subsection{The pentagonal shape that dominates the architectural expression of $\mathrm{BPH}$ building}

The site of BPH building was positioned at the corner of a three-way junction, right at the end of a triangular complex (refer to Fig. 2a). It is delineated by the Eyckman street, which is one of the main streets in Bandung. Thus, this building was easily seen by all visitors who strolled through this street. While nearing the site entrance, the first thing that can be identified is a part of the side view of the building. It appears that this two-story building has a hip roof, with a unique end-shape; not a straight and closed-end like a usual hip roof, but looks like the end-shape of the gable roof. Under the roof, there is a white wall with an additional wall on the left side that is tilted at an angle. Appearing with a brighter colour, the tilted wall seems contrasted to the main wall. Overall, this building was visually dominating due to the position of its site, as well as the shape of the roof and tilted walls (Fig. 5).
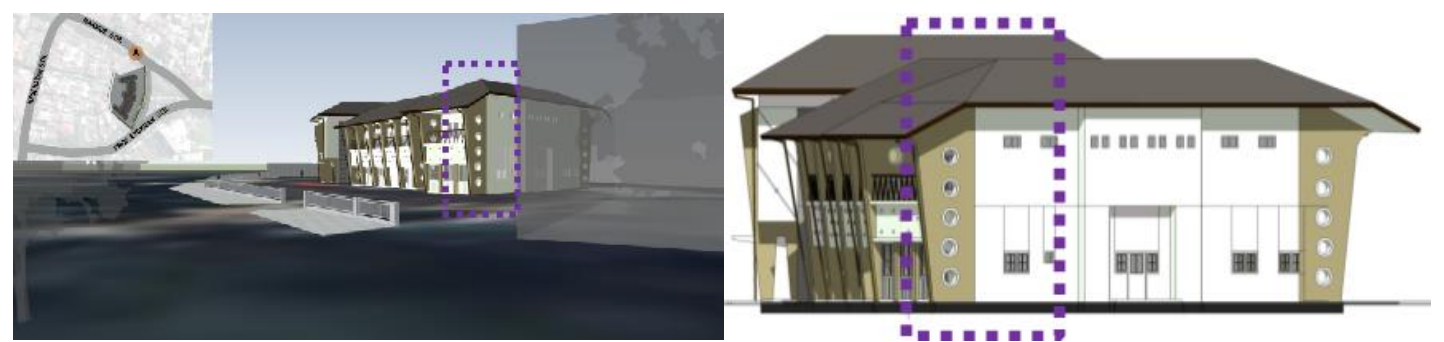

Fig. 5. Architectural expression of BPH Building as observed from point A. From this distance, the most dominating element is the tilted wall

Entering the site, the overall shape of the building can be seen more clearly. Other dominant architectural element is the subtraction of the balconies wall in a circular shape, about $10 \mathrm{~cm}$ in diameter. These holes are arranged regularly according to a particular grid. The design of the balconies wall resembles the motifs of indigenous ventilation block called 'krawang' (Fig. 6a). Besides serving as decorative element, these balcony walls also serve as an exterior shading device. The tilted walls and the use of krawang make the $\mathrm{BPH}$ building appears different from other buildings in the area, most of which are modern buildings and are dominated by rectangular walls and flat roofs. 


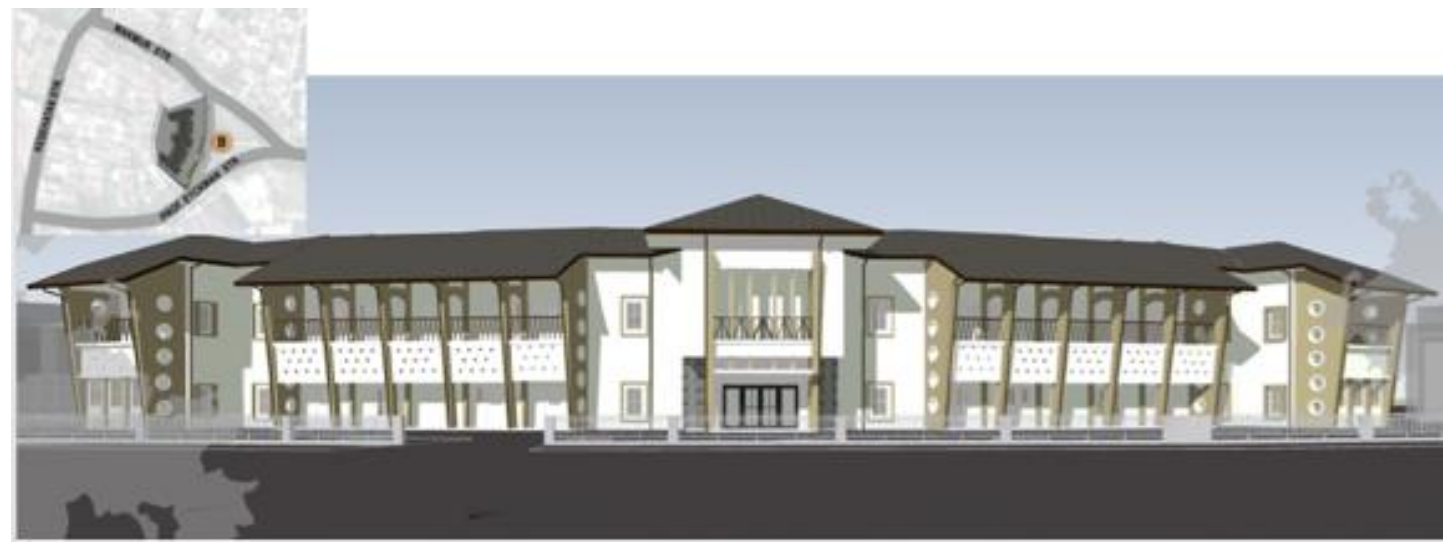

Fig. 6a. The ventilation blocks 'krawang' and tilted wall as observed from point B
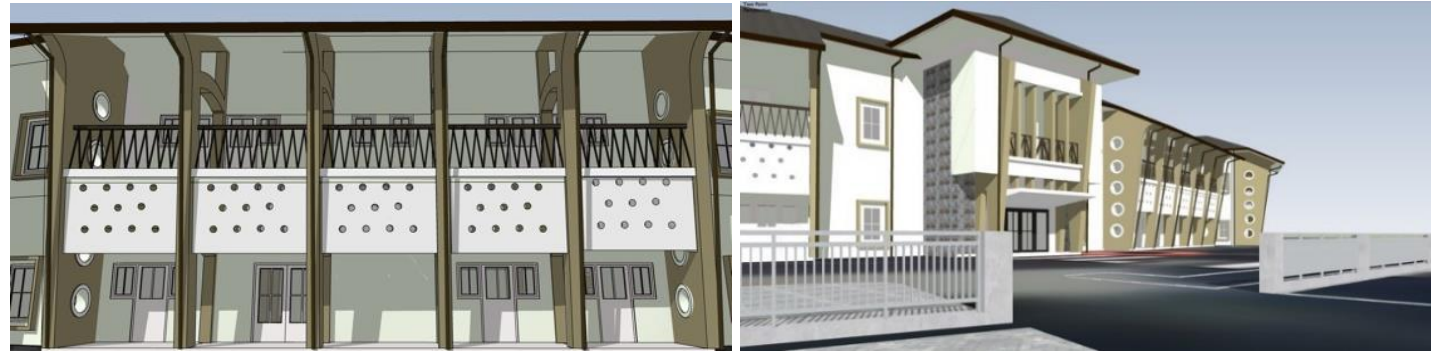

Fig. 6b. Closer view of the krawang and the tilted walls

Another observation of the overall shape of the building shows that there is a dominant expression of horizontal motion resulting from a ratio of height and length of the building. This horizontal expression is very different from European-style or Indische-style architecture that tends to be monumental, with a vertical motion dominating its expression (Fig. 7).

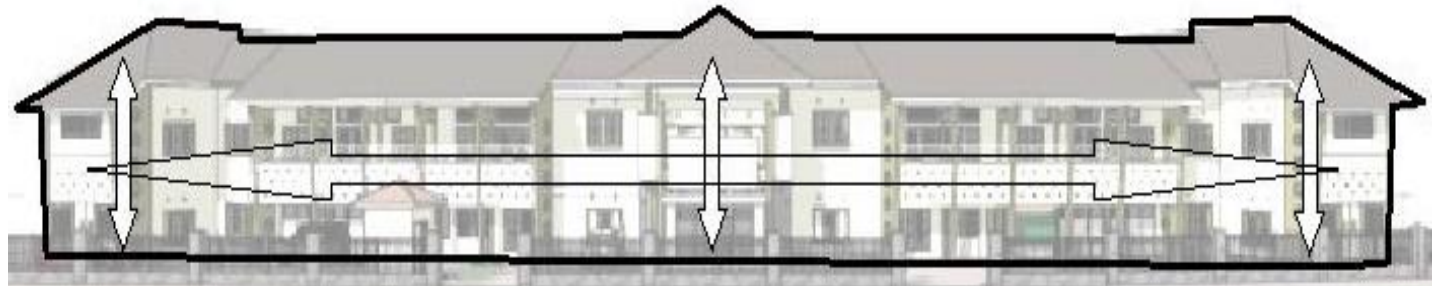

Fig. 7 Horizontal motion of BPH Building

Historical records show that this building was initially intended as a dormitory for nurses. Only in 1990, it functioned as a vocational university. In accordance with its function as a forum for educational activities that require formal expressions, the configuration of the building masses, facades, and the spatial layout is arranged symmetrically. While designed following the curved shape of the site; the division of inner space is very efficient. The configuration of inner spatial layout adopted a single loaded system, with an open corridor facing the inner court as circulation area.
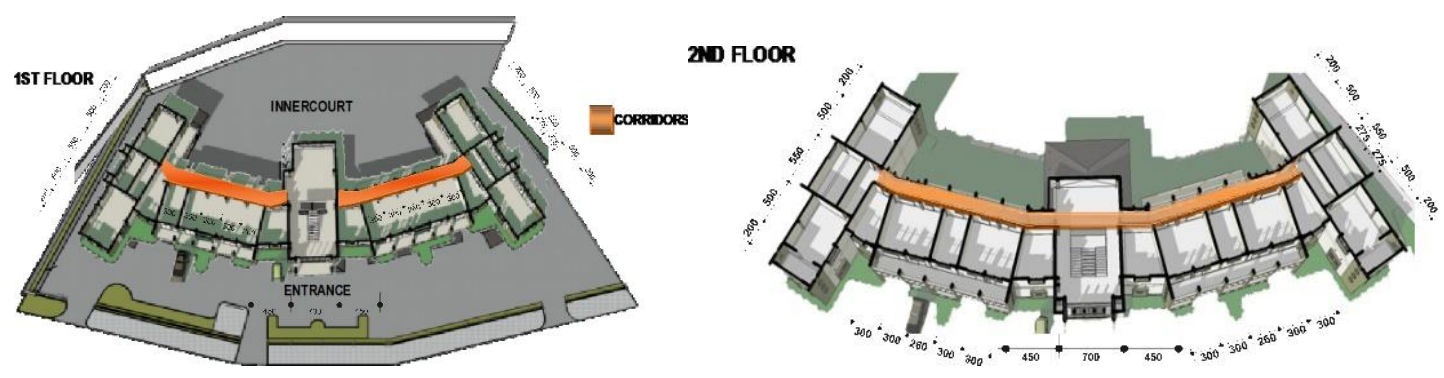

Fig. 8. Symmetrical and single-loaded configuration of the building 
The structural and construction system is almost similar to other buildings in general. All of the inner walls divide the interior of the building in line with the structural grid. No interior walls were found tilted in line with the angle of the structural column, except for the balcony walls that tilted following the angle of the structural column (Fig. 9). Based on the results of the redrawing, it can only be seen that building elements that look like tilted walls from the outside are structural columns that function as roof supports. The combination of the tilted wall and column with a simple roof structure creating a unique structure, which resembles the shape of a five-sided polygon (pentagon). Overall, the most dominating elements that generated the characteristic of Jengki-style architecture is the configuration of structural elements in the shape of pentagon, and the use of ventilation blocks in building's facade (Fig 10).

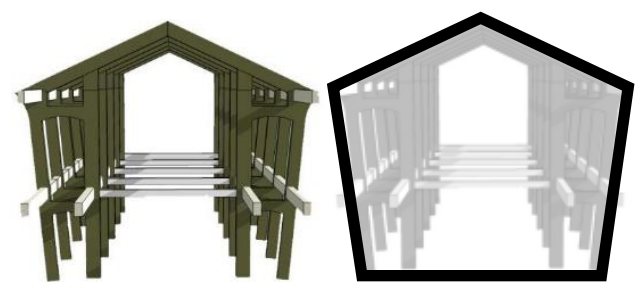

Fig. 9. The configuration of structural elements that resembles a pentagon

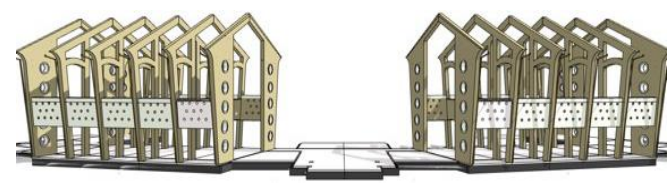

Fig. 10. The pentagonal shape and ventilation blocks as the most defining characteristic of Jengki-style architecture in BPH Building

\subsection{The pentagonal shape that dominates the architectural expression of BS Meeting Hall}

The site of the BS building is located in a residential area on the Kiputih street, which can be accessed from Ciumbuleuit street. Although it is not possible to be seen from Ciumbuleuit street, the site itself is positioned at the end of a crossroad, so it is quite easy to be seen. Entering the Kiputih street, visitors could see the signage of Bumi Sangkuriang Meeting Hall, and a stone fence covered in vegetation. The building itself can only be seen when visitors were nearing the site entrance; showing its brown-coloured roof made from shingles, and the tilted wall under the roof. Differ from the BPH Building; there is no pentagon shape that could be seen from afar.

The BS building sits on the L-shaped site, positioned on the side that facing the Kiputih street. Observed from the site entrance, it looks like a sizeable single-mass building, but further observations show that this building consists of the main building with several supporting buildings positioned far enough on the west side of the site. However, the discussion will focus only on the main building, which was the original building built in 1957. Observed from the eastern end of the site, it can be seen that the main building consists of 3 masses arranged asymmetrically, with different roof elevations. Highlighting the importance of the lobby area, the mass is positioned in the middle and has the highest roof elevation compared to the other masses (Fig. 11). The main building is covered by two gable roofs set in different heights, with the upper wall tilted at an angle. Nevertheless, the lower wall, which is the most dominant part of the building, tends to be rectilinear. Unlike the Jengki buildings in general, there is no tilted wall that accentuates the shape of the pentagon (Fig. $12 \mathrm{a}-\mathrm{b})$. Thus, the overall expression is no different from a general gable-roofed building. When viewed from the site entrance, the building characteristics that dominating the overall expression are the lower-wall of the building which is coated with vegetation, and the tilted upper-wall which are made of woods that resemble traditional houses in Indonesia. The expression of building's material is reminiscent of local buildings in Indonesia but does not indicate specifically about its architectural style.

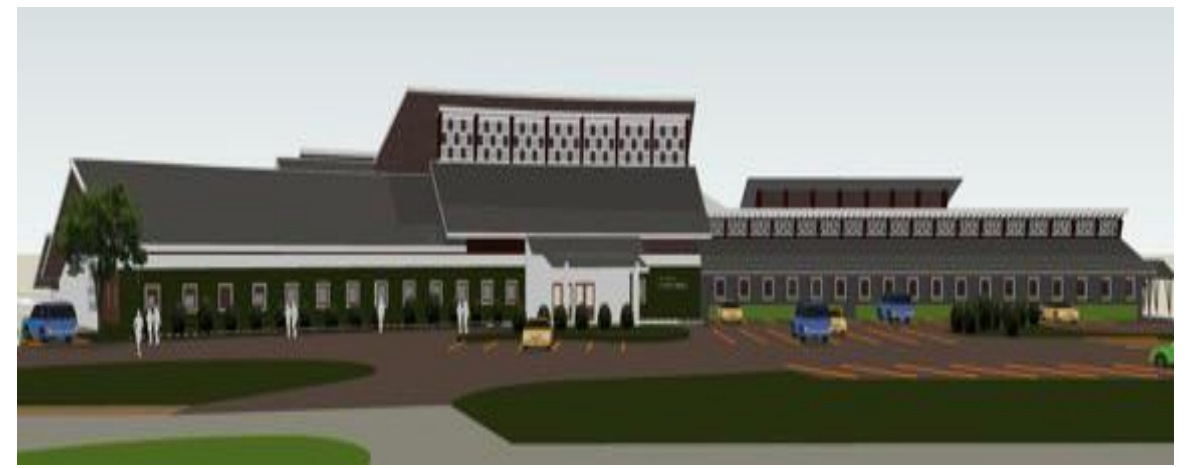

Fig. 11 Front elevation of BS building 


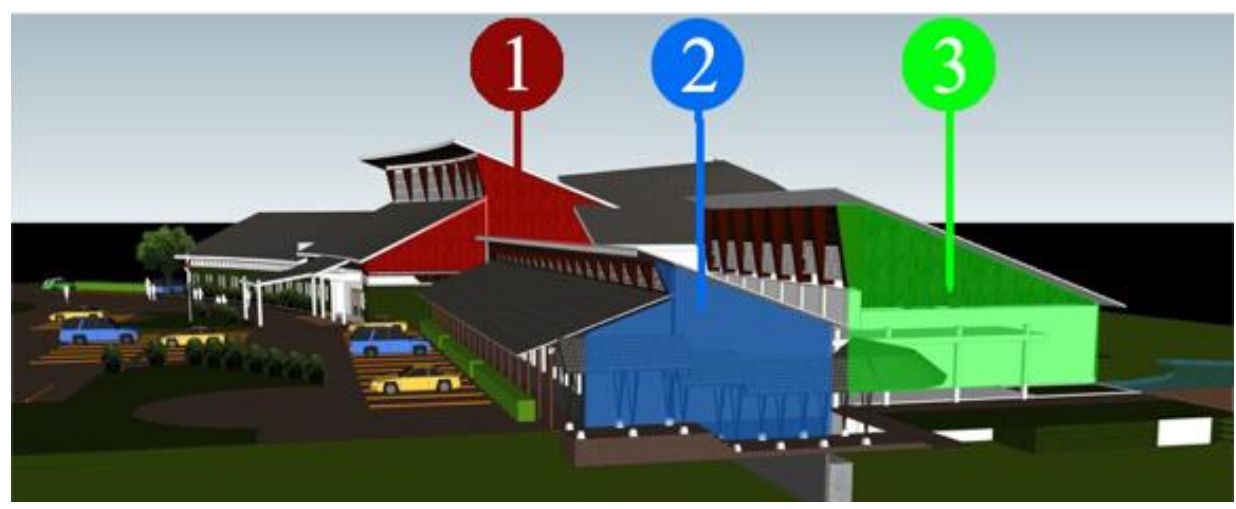

Fig. 12 a. Side elevations of BS building. Some of the main building's walls (1\&2) still forms a pentagon but more obscured without the tilted wall

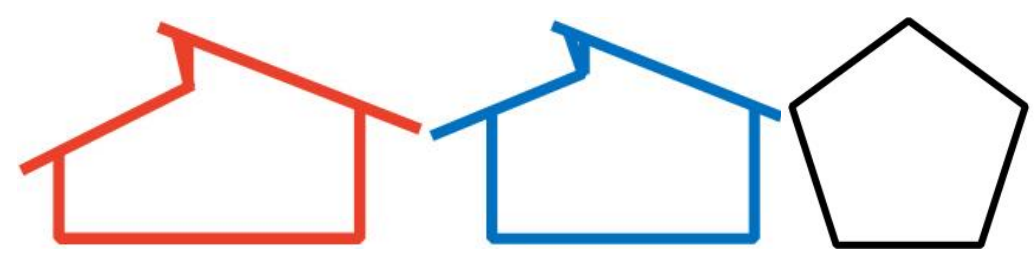

Fig. 12 b. Comparison between the shape of side elevations with the shape of pentagon 
The overall form of the BS building tends to be curved, almost the same as the BPH building. But unlike $\mathrm{BPH}$, which has a symmetrical arrangement, the composition on the BS building tends to be asymmetrical (Fig. 13). This characteristic distinguishes the building from the majority of Indische-style buildings which generally tend to be symmetrical.

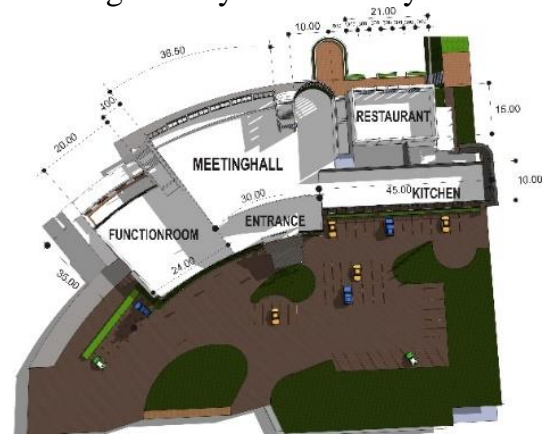

Fig. 13 Asymmetrical layout of BS building

Identical to the exterior walls, there is no sign of tilted walls inside the building. In the meeting hall and restaurant, the ceiling is sloped following the slope of the roof. Right under the ceiling, there are several ventilation blocks (krawang) made from concrete materials (Fig. 14). Besides serves as decorative elements, these blocks also function as natural ventilation. Over time, the use of ventilation blocks is considered as one of the characteristics of buildings in tropical countries. In general, the selection of the elements of the gable roof and the scope of the building material shows that this building has a visual similarity with buildings in tropical countries, while at the same time pragmatically fulfilling the function of air and natural lighting which is also suitable for tropical regions. However, without knowing in advance that the designer intended to adapt the Jengki style to be applied to its architecture, it is very difficult to classify this building as a Jengki-style building that represents the ideology of the post-independence Indonesian people.

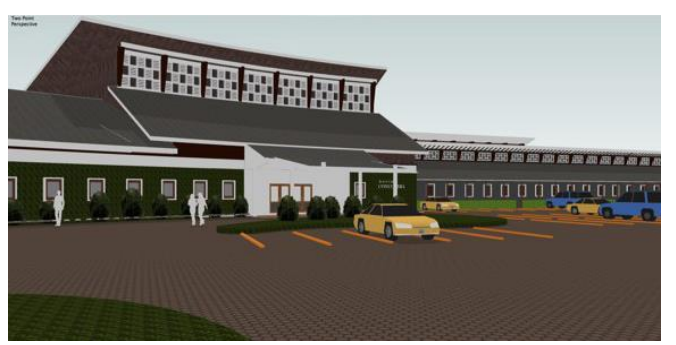

Fig. 14a. Ventilation blocks 'krawang' that dominated the overall expression of $\mathrm{BS}$ building
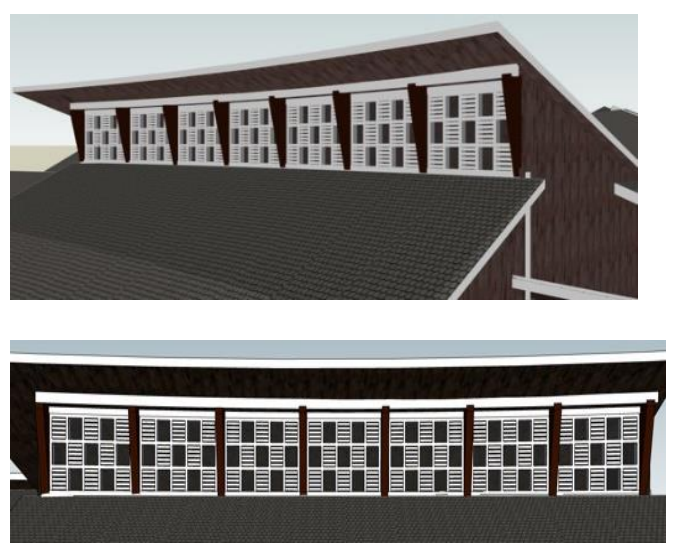

Fig. 14b. Closer view of ventilation blocks

\subsection{The icono-symbolical meanings of Jengki architectural style and its future application}

The literature concerning the history and development of Indonesian architecture rarely mentions that at a certain period postindependence, there is an architectural style that symbolized the spirit of independence and nationalism, which resembles the form of an equilateral pentagon. What is often mentioned is that at that time, President Soekarno adopted the International Style Architecture to be applied to public buildings, to represent the modern Indonesian state. In other literature, it is also mentioned that in line with the term 'Yankee', Jengki buildings was vaguely similar to the American-style buildings (Khalil, 2017). These remarks still tend to be a mere opinion without comprehensive scholarly works and cannot be proven empirically; as in the United States, both past and present, there has never been found an architectural style known as Yankee-style architecture. The description of the case studies also shows that they do not have any similarity to the architectural works 
from other countries, let alone those from the United States. On the contrary, other literature states that President Soekarno as the originator of the Jengki architecture, never suggested adopting any trend originating from other developed countries. At that time, it was Indonesian culture that was about to be promoted and introduced to other countries, not the other way around. It is essential to understand that Jengki architectural style with all its characteristics, was born and developed in this particular context. Therefore, the Jengki buildings should not be interpreted literally, but more in-depth, i.e. on the context of the spirit of anti-colonialism.

Previous research on Jengki buildings tends to be done by dissecting and classifying their parts of architectural elements. Analyzed separately, it only shows that it posses no exceptional characters; that it was just the same as other buildings in any tropical regions (Setyabudi et al., 2011; Triyosoputri, 2008). From these studies, one can interpret that all of the architectural elements that formed the Jengki buildings are mere, fulfilling its pragmatic requirements. This research shows that all of its architectural elements must be seen as a whole. This research shows that in the $\mathrm{BPH}$ building, the shape of all architectural elements such as walls, columns, and the roof is configured to create an icon of an equilateral pentagon, to symbolize the five principles of Pancasila. In the architecture of BS building, some of the side walls still forms a pentagon but more obscured without the tilted wall. Thus, the shape of the pentagon perceived by observers is not as clear as the shape of the pentagon that could be seen on the original Jengki-houses in Kebayoran (Fig. 15).

The similarity of architectural configuration with the symbol of Pancasila can be classified as the type of iconic sign. However, it is not merely mimicking the symbol (Fig. 16), but from the results of a critical interpretation of the underlying philosophy of Pancasila itself. Although it seems to be arranged hierarchically, each of these five principles must be seen as interconnected wholeness; the fulfilment of one principle must be given the same degree of importance with the four other principles. Viewed in this context, the shape of a pentagon that has five sides of equal length (equilateral pentagon) is more capable of representing the philosophical basis of Pancasila. Furthermore, the Pancasila itself is the result of a convention that the five principles serve as the basis of the new Indonesian state. In other words, Pancasila could be interpreted as a symbol of the state. Without prior knowledge of the Pancasila and the philosophical stance that underlies it, observers cannot possibly understand that this architectural form represents the ideology and spirit of Indonesian people's nationalism. Based on these arguments, architectural elements that resemble the shape of a pentagon classified as iconic signs which are at once symbolic in nature (icono-symbolic).

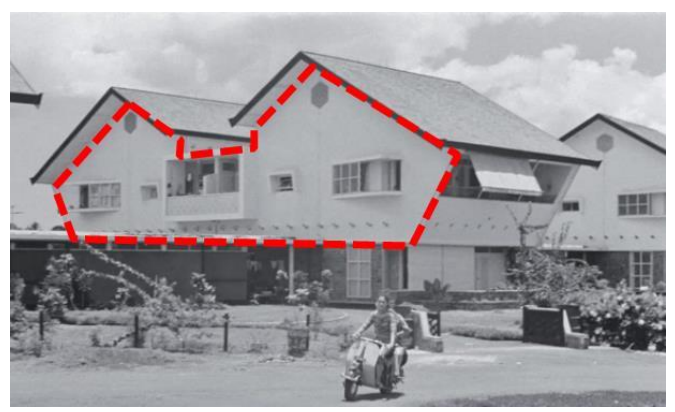

Fig. 15 The double-pentagonal shape in the first Jengki-style house in Kebayoran Source: (Khalil, 2017) 


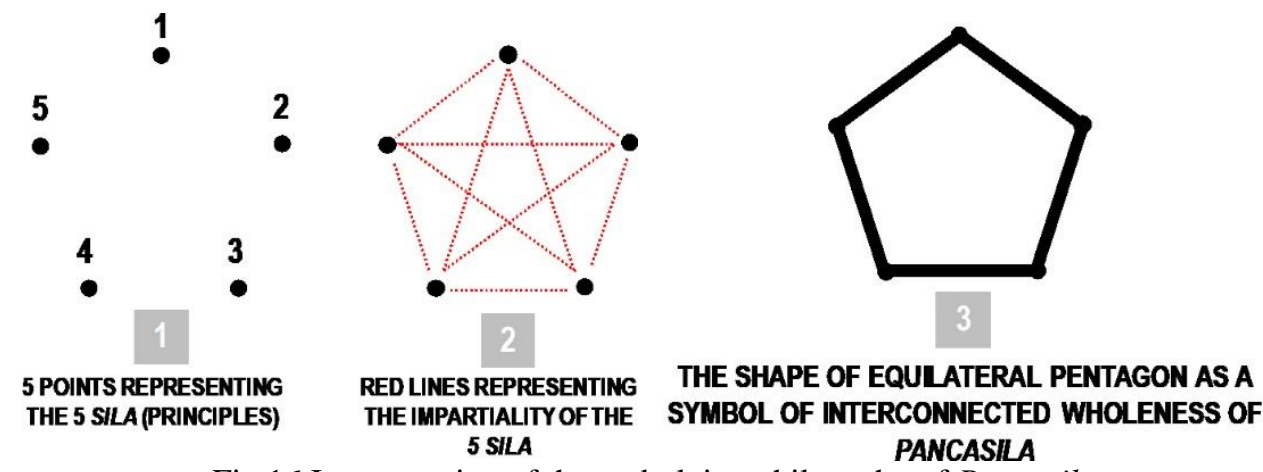

Fig.16 Interpretation of the underlying philosophy of Pancasila

Besides having a distinctive shape, the abstraction of the pentagonal shape is also suitable for Indonesia's tropical climate. The gable roof with extended width, which formed the top side of the pentagon, can be at the same time useful as a barrier to the glare of tropical sunlight entering the building. Thus, aside from being an icon of the Pancasila, the shape of Jengki-style buildings can also inform observers that this is a building that was built in a tropical climate (Fig. 17). Similarly,

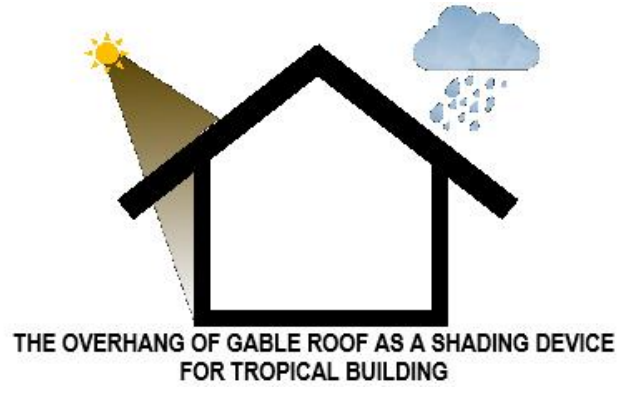

Fig. 17 The pentagon as an icon of tropical buildings

Another characteristic of Jengki architecture is the expression of freedom because it was created to reflect the spirit of post-colonial independence. This is often shown by the asymmetrical arrangement of the mass and the playful articulation of ornaments. Nevertheless, the spatial layout, as well as the facade of BPH building, is actually symmetrical in composition. This might be due to the fact that this building is a public building that requires formal expression. From this example, it can be seen that the Jengki style that is generally asymmetrical in residential houses is not just adopted, but also adapted to the activities contained by the building. Despite having some unique characteristics, the flexibility of this style actually allows it to be because it has a configuration that is suitable for the local climate, the building is believed to be sustainable in a long period of time. As an icon, the application of this pentagonal shape not only can be positioned on the side elevation, but on the entire composition, or as an element to mark the building entrance. The position of the pentagon on the overall appearance will be much easier to identify than the shape of the pentagon which tends to only be found in building's floor plans.

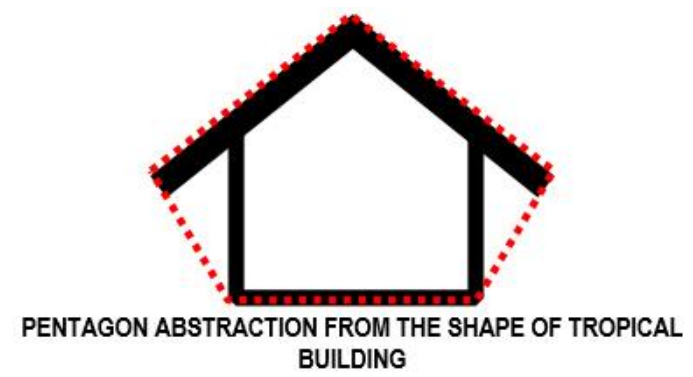

applied to buildings with a variety of functions. The survival of Jengki architecture and its possibility to be applied to modern buildings is also supported by the use of local materials, which have been proven to be suitable for tropical climate 


\section{CONCLUSION}

Based on the results of the analysis, it can be concluded that:

Firstly, the emergence of Jengki architecture represents the spirit of nationalism and anticolonialism. In the case study that still apply the Jengki architectural style, the composition of all building elements from roofs to tilted columns and walls aims to create a shape that resembles a five-sided polygon (pentagon). The use of equilateral pentagon is the paramount characteristic of Jengki architectural style, as it symbolizes the unity of five foundational principles of post-colonial Indonesian state (Pancasila). Other characteristics of Jengki architecture, i.e. the use of local materials, asymmetrical configurations, and playful articulation of ornaments symbolize the spirit of freedom of the post-colonial Indonesian. Differ from the elements of traditional architecture which represent particular ethnic groups, this equilateral pentagon can be proposed and developed as an icon of Indonesian architecture nationwide. This pentagonal shape can be directly applied by practitioners who intended to design buildings that express national identity. For example, in the design of the administrative building in the capital city of Indonesia.

Secondly, this research adds another layer of understanding to the theory of architectural icon put forward by Sklair and Panofsky. It also offers a new alternative in researching architectural concepts that already exist in Indonesia, i.e. through the exploration for architectural icons and their possible application in the future. This research could also provide an alternative method in analyzing any architectural works. Instead of dissecting the buildings into parts and classify all of the architectural elements mechanistically, this study shows that the iconic meaning of the building can only be interpreted in-depth when it was observed as a whole. The results of this interpretation are proven to differ from "mechanistic studies" which generally lead to simplistic interpretations and are less successful in revealing the concepts underlying the architectural style.

Thirdly, an in-depth understanding of the iconic and symbolic concept of Pancasila which underlies the Jengki architectural style will contribute to all stakeholders involved in rebuilding and renovating Jengki buildings. Moreover, the practise of architectural conservation should promote the Jengki architectural icon, as in the future, this icon has the potential to the creation of a NationalIndonesian architecture.

Fourthly, the results of this study can be a source of inspiration and a theoretical basis for further and more detailed research into the concepts underlying the birth of a specific architectural style, as well as exploring the icons of the architectural style to be applied to contemporary buildings in the future. Other research which aimed at improving, complementing, or even discussing the weaknesses of this research could serve an important input for enriching architectural knowledge.

\section{REFERENCES}

1. Amelita. (2012). Penerapan Gaya Arsitektur Jengki pada Bangunan Politeknik Kesehatan Bandung. Parahyangan Catholic University. Unpublished Undergraduate Thesis.

2. Aning, F. (2019). Lahirnya Pancasila Kumpulan Pidato BPUPKI (F. Aning (ed.)). Media Pressindo.

3. Ardhiati, Y. (2005). Bung Karno Sang Arsitek: Kajian Artistik Karya Arsitektur, Tata Ruang kota, Interior,Kria, Simbol, Mode Busana dan Teks Pidato 1926-1965. Komunitas Bambu.

4. Chandra, R. (2012). Pengaruh Spirit Lokal pada Arsitektur Gedung Sate (Governement Bedrijven) dan Aula Barat ITB (Kompleks Technische Hoogeschool) di Bandung. Parahyangan Catholic University. Unpublished Master Thesis.

5. Crysler, G., Cairns, S., \& Heynen, H. (2012). The SAGE Handbook of Architectural Theory. SAGE Publications Ltd.

6. Dariyanto, E. (2016, June 1). Ini Pidato Bung Karno 1 Juni 1945 yang Jadi Cikal Bakal Lahirnya Pancasila. Detiknews.

7. Deledalle, G. (2001). Charles S. Peirce's Philosophy of Signs: Essays in Comparative Semiotics. Indiana University Press.

8. Dovey, K. (1999). Framing Places: Mediating Power in Built Form. Psychology Press.

9. Eranio, A. (2015). Tinjauan BP Bumi Sangkuriang sebagai Bangunan Jengki. 
Parahyangan Catholic University. Unpublished Undergraduate Thesis.

10. Freeman, C. G. (2013). Participatory Culture as a Site for the Reception of Architecture: Making a Giant Sydney Opera House Cake. Architectural Theory Review, 18(3), 325339.

11. Gielbels, L. J. (2015). Sukarno, A Biography (Kindle). Fosfor International.

12. Harland, R. G., \& Liguori, A. (2016). Traces of fascist urban iconography in the Latina Province, Italy. International Association for Media and Communication Research (IAMCR 2016).

13. Ismail, S., Ahmad, Y., \& Hamzah, H. (2008). Heritage conservation for city marketing: The imaging of the historic city of Georgetown, Penang. Journal of Design and the Built Environment, 4(1), 27-40.

14. Khalil, T. (2017). RETRONESIA: The Years of Building Dangerously. Equinox Publishing.

15. Kurniawan, K. R., \& Kusumawardhani, R. A. (2012). The influence of 19th century Dutch Colonial Orientalism in spreading Kubah (Islamic Dome) and Middle-Eastern architectural styles for mosques in Sumatra. Journal of Design and the Built Environment, 11(1), 1-13.

16. Kusno, A. (2000). Behind the postcolonial: Architecture, urban space and political cultures in Indonesia. In Architext (1st ed.). Routledge.

17. Mariana, Y. (2013). Tipologi Bangunan di Jalan Pakubowono Kebayoran Baru, Jakarta Selatan. ComTech: Computer, Mathematics and Engineering Applications, 4(1), 33-42.

18. Merrell, F. (1997). Peirce, Signs, and Meaning. University of Toronto Press.

19. Minkenberg, M. (2014). Power and Architecture: The Construction of Capitals and the Politics of Space (Space and). Berghahn Books.

20. Panofsky, E., \& Panofsky, G. S. (1972). Studies in Iconology: Humanistic Themes in the Art of the Renaissance. Routledge, Taylor and Francis Group.
21. Peirce, C. S. (1991). Philosophical Writings of Peirce (J. Buchler (ed.)). Dover Publications.

22. Prakoso, I. (2002, February 17). Arsitektur Jengki, Perkembangan Sejarah yang Terlupakan. Harian Kompas.

23. Ratri, W. (2016). Bandung Jengki from Heritage Point of View: Documentation and Preliminary Search on Significance. DIMENSI (Journal of Architecture and Built Environment), 43(1), 55-66.

24. Sadowski, P. (1957). From Interaction to Symbol: A systems view of the evolution of signs and communication. John Benjamins Publishing Company.

25. Salura, P. (2018a). Anatomy of Architecture Based on the Creation of Space for Activity. International Journal of Engineering and Technology(UAE), 7(2.14), 205-207.

26.Salura, P. (2018b). Spectrum of Meaning in The Architecture of Catholic Church. International Journal of Engineering and Technology(UAE), 7(2.14), 317-322.

27. Salura, Purnama. (2015). Rethinking Architectural Design Studio Education in Global Era. International Journal of Academic Research, 7(3), 218-221.

28. Salura, Purnama. (2018c). The Philosophy of Architectural Ordering Principles. International Journal of Engineering and Technology(UAE), 7(2.9), 52-55.

29. Salura, Purnama, \& Clarissa, S. (2018). Interpreting Architectural Expression of House of Representative Building, Case study: East Java Provincial House of Representative Building in Surabaya, East Java, Indonesia. Journal of Advanced Research in Dynamical and Control Systems, 02-Special Issue, 1543-1552.

30. Salura, Purnama, Clarissa, S., \& Lake, R. C. (2020). The Application of Sundanese Vernacular Concept to The Design of Modern Building - Case Study: Aula Barat (West Hall) of Bandung Institute of Technology, West Java, Indonesia. Journal of Design and Built Environment, 20(1), 112.

31. Setyabudi, I., Nugroho, A. M., \& Antariksa. (2011). Makna Lokal Rumah Tinggal 
Bergaya Jengki di Kota Malang. Universitas Brawijaya.

32. Sholihah, A. B., Agustiananda, P. A., Junanah, \& Setiawan, W. (2019). Traditional architecture: The role of traditional festival in islamic historic district to achieve local community wellbeing. Journal of Design and Built Environment, 19(3), 13-23.

33. Sklair, L. (2011). Iconic Architecture and Urban, National, and Global Identities. In D. E. Davis \& N. L. De Duren (Eds.), In Cities \& Sovereignty: Identity Politics in Urban Spaces (pp. 179-195). Indiana University Press.

34. Sklair, L. (2017). The Icon Project: Architecture, Cities, and Capitalist Globalization. Oxford University Press.

35. Smith, T. (2003). The dialectics of disappearance: architectural iconotypes between clashing cultures. Critical Quarterly, 45(1-2), 33-51.

36. Sudjic, D. (2005). The Edifice Complex: How the Rich and Powerful Shape the World. Penguin Press HC.

37. Sudradjat, I. (1991). A Study of Indonesian Architecture History. University of Sydney. Unpublished Doctoral Thesis.

38. Sukarno. (2019). Filsafat Pancasila Menurut Bung Karno (F. Aning (ed.); 4th ed.). Media Pressindo.

39. Susilo, G. A. (2009). Arsitektur Jengki: Bergeometri yang Kreatif. Spectra, 7(13), 15-23.

40. Susilo, G. A., Pramono, Y. S., \& Suharjanto, D. (2012). Studi Geometri pada Tampang Rumah Jengki di Kota Malang. Spectra, 10(20), 11-25.

41. Tombesi, P. (2005). Iconic Public Buildings as Sites of Technological Innovation. Harvard Design Magazine, 21, 1-5.

42. Triyosoputri, E. (2008). Bangunan BerArsitektur Jengki di Malang: Kajian terhadap Elemen Fasade; Kasus: Rumah Dinas PT. Pindad (Persero) Turen. Universitas Merdeka Malang.

43. Vale, L. (2008). Architecture, Power and National Identity (2nd ed.). Routledge,
Taylor and Francis Group. Watson, H. C. (1851). The Yankee Tea Party: Or Boston In 1773. Lindsay and Blakiston.

44. Widayat, R. (2006). Spirit dari Rumah Gaya Jengki Ulasan tentang Bentuk, Estetika, dan Makna. Dimensi Interior: Jurnal Desain Interior, 4(2), 80-89.

45. Yang, T. (2014). The Design Patterns of Administrative Building: Precedent Studies and Designing Fenggang Administrative Center [School of Architecture, University of Hawai'i].

46. Zakky. (2018, July 16). Gambar Lambang Pancasila dan Artinya dari Sila ke 1 Sampai 5. Zona Referensi Ilmu Pengetahuan Umum. 